\title{
C. C. A. Christensen, Joseph Preaching to the Indians
}

\section{Nathan Rees}

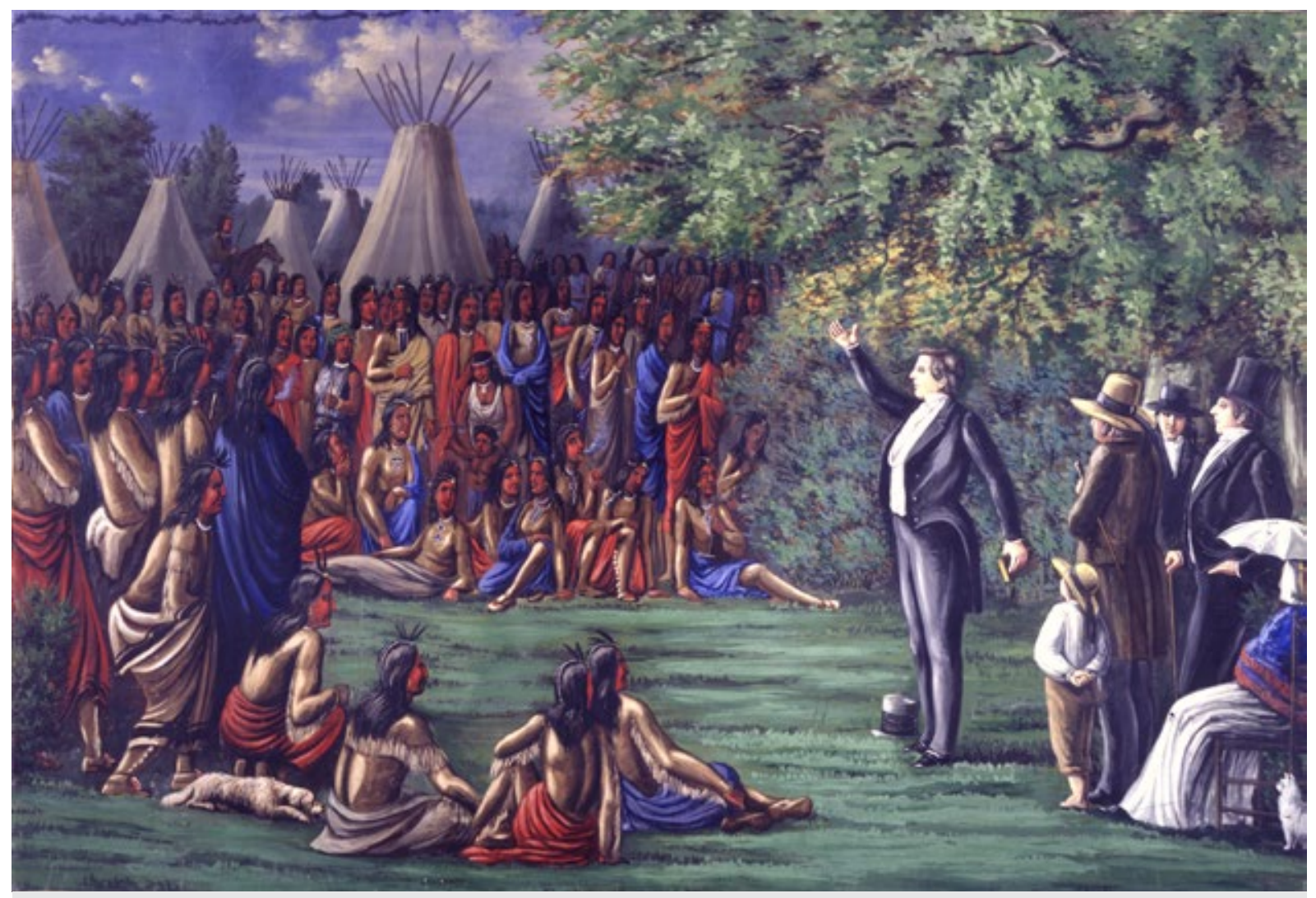

C. C. A. Christensen, Joseph Preaching to the Indians, ca. 1865

Joseph Preaching to the Indians is a scene from the Mormon Panorama, a series of twenty-three paintings produced by Mormon artist C. C. A. Christensen. Beginning in 1879, Christensen toured the Intermountain West with the panorama, scrolling scene by scene as he lectured about the founding of the Church of Jesus Christ of Latterday Saints. ${ }^{1}$ Although Joseph Preaching to the Indians depicted a historical event, it would have held contemporary significance for its late-nineteenth-century audience. For Mormon settlers living around Christensen's central Utah home, the memory of the 1860 s Black Hawk War, a sustained conflict between Native Americans and Mormon settlers, was still fresh. ${ }^{2}$ The painting conveys a deep ambivalence underlying Mormon relations with American Indians. Although LDS doctrine esteemed Native Americans as literal descendants of the peoples of the Book of Mormon, relations between Mormons and Indians in Utah grew increasingly strained as resources became scarce. Christensen's work reflects this divided perspective, simultaneously advancing an idealized LDS hope for the possibility of converting and integrating Indians into Mormon society, while also reifying systemic nineteenth-century stereotypes that some settlers used to justify exploitative actions. 
The painting depicts Joseph Smith, founder of the LDS Church, addressing a group of Sauk or Fox Indians near the Mormon settlements in Illinois around $1840 .{ }^{3}$ His message was that American Indians were descended from Israelites who had sailed to the Americas to escape the Babylonian conquest of Jerusalem. Once Indians reclaimed this heritage by joining the LDS Church, he asserted, they would receive blessings promised by the Book of Mormon and take a leading role in building the New Jerusalem in America. ${ }^{4}$ This message emphasized unity: LDS leaders in early Utah were hopeful that area Indians would become part of the kingdom of Zion. Only by working together could they fulfill their divine mandate. ${ }^{5}$ Christensen's composition literalizes this metaphor of interdependence: the Indians are grouped in a nearly-full circle, completed only by Joseph Smith and his Mormon companions. The interlocking arrangement of the two groups neatly expresses the LDS view that their religious destinies were inextricably intertwined.

In the Utah Territory, this conception of religious commonality translated into tangible policies: Joseph Smith's successor, Brigham Young, granted Native Americans membership in the LDS Church and, at times, advocated a policy of pacifism that Mormons hoped would encourage Indians to embrace their religion. ${ }^{6}$ Nonetheless, many nineteenth-century Mormons viewed Indians through the lens of pervasive contemporaneous stereotypes, seeing little value in Native American cultural practices. Mormon writers frequently equated the Indians' rediscovery of their alleged religious heritage with the acceptance of Western cultural values; becoming more like their righteous Book of Mormon ancestors meant becoming more like their contemporary Mormon neighbors. Adding to the strife caused by cultural differences, Mormon settlers were putting stress on Indian populations by competing for land and resources, and resulting conflicts sometimes sparked episodes of violence. ${ }^{7}$

Despite its overtly positive message about Native Americans, Christensen's work reflects then-current stereotypes; rather than representing any of the specific native peoples with whom he had contact, Christensen depicted generic Indians of the sort that pervaded nineteenth-century American visual culture. ${ }^{8}$ In particular, the image reinforces the deeply ingrained contemporary trope that associated Indians with nature rather than culture. ${ }^{9}$ Though the Mormons stand out dramatically from the background, the Indians blend in with their surroundings, merging with the greenery in the center foreground and peering out from behind bushes. Additionally, Christensen mirrored the tipis of the Indian encampment with a Mormon woman seated on a chair and shaded by an umbrella. Her emblems of domesticity emphasize Christensen's understanding of the Indians' comparatively uncivilized status. ${ }^{10}$ The lighting in the painting reinforces this conception; Joseph Smith and his associates are brightly lit while the Indians, their backs to the light, disappear into the background shadows.

Christensen's image delicately balanced competing attitudes toward Native Americans. While its subject and circular composition convey the LDS Church's ambition to convert the Indians and make them co-builders of Zion, it follows contemporaneous stereotypes in portraying American Indians as uncivilized and lacking in culture. More than simply illustrating a scene from LDS Church history, Joseph Preaching to the Indians 
emblematized the settlers' shifting and discordant views during a period when the attempt to peacefully integrate Indians into Mormon communities seemed increasingly less tenable. ${ }^{11}$

(C) Nathan Rees

\section{Citation Guide}

1. Nathan Rees, "C. C. A. Christensen, Joseph Preaching to the Indians," Object Narrative, in Conversations: An Online Journal of the Center for the Study of Material and Visual Cultures of Religion (2014), doi:10.22332/con.obj.2014.48

Rees, Nathan. "C. C. A. Christensen, Joseph Preaching to the Indians." Object Narrative. In Conversations: An Online Journal of the Center for the Study of Material and Visual Cultures of Religion (2014). doi:10.22332/con.obj.2014.48

\section{Notes}

1. For a biography of C. C. A. Christensen, see Richard L. Jensen and Richard G. Oman, C. C. A. Christensen, 1831-1912: Mormon Immigrant Artist (Salt Lake City: LDS Museum of Church History and Art, 1984). The Christensen family continued exhibiting the Mormon Panorama into the early twentieth century-it is now in the collection of the Brigham Young University Museum of Art.

2. Though the worst violence occurred between $1865-1867$, peace was not fully restored until federal troops began enforcing Ute confinement on the Uintah Reservation in 1872. See John Alton Peterson, Utah's Black Hawk War (Salt Lake City: University of Utah Press, 1998).

3. In Christensen's lecture accompanying the panorama, he did not refer to a specific incident but noted that Joseph Smith had preached to Indian groups on many occasions. For a history of these encounters, see Lawrence Coates, "Refugees Meet: The Mormons and Indians in Iowa," BYU Studies 21 (Fall, 1981): 491-514. Christensen's lecture is preserved in the Americana Collection, L. Tom Perry Special Collections, Harold B. Lee Library, Brigham Young University.

4. This narrative is primarily from the First and Second Books of Nephi in the Book of Mormon, as well as in Third Nephi chapter 21. For an exploration of these themes in Mormon Theology, see Armand Mauss, All Abraham's Children: Changing Mormon Conceptions of Race and Lineage (Urbana: University of Illinois Press, 2003).

5. See, for example, Orson Pratt, "Discourse Delivered in the Twentieth Ward Meetinghouse on the Evening of Sunday, February 7, 1875," in Journal of Discourses (Liverpool: George Q. Cannon, 1875), 285-306. 
6. Although Young frequently repeated the maxim that it is "cheaper to feed the Indians than to fight them," his policy toward American Indians was constantly in flux, shifting pragmatically in relation to individual circumstances; while he worked to maintain peaceful relations, he also sometimes sanctioned violence as a punitive measure against Indians who resisted colonization. See Floyd A. O'Neil and Stanford J. Layton, "Of Pride and Politics: Brigham Young as Indian Superintendent," Utah Historical Quarterly 46, no. 3 (Summer, 1978): 236-250; John G. Turner, Brigham Young: Pioneer Prophet (Cambridge, MA: Belknap Press, 2012), 207-218.

\section{Yale}

